\title{
Conservation Tillage and Organic Matter management on Soil Structure
}

\author{
Abdul Aziz Khalid ${ }^{1}$, Henry Oppong Tuffour ${ }^{2 \star}$, Awudu Abubakari ${ }^{2}$ and Samuel Novor \\ ${ }^{1}$ Department of Horticulture and Crop Production, University of Energy and Natural Resources, Dormaa-Ahenkro, Ghana \\ ${ }^{2}$ Department of Crop and Soil Sciences, Kwame Nkrumah University of Science and Technology, Kumasi, Ghana
}

\section{Article Info}

\section{*Corresponding author:} Henry Oppong Tuffour

Department of Crop and Soil Sciences Kwame Nkrumah University of Science and Technology

Kumasi, Ghana

E-mail: hoppongtuffour@gmail.com

\section{Received: November 21, 2018 \\ Accepted: December 24, 2018 \\ Published: January 3, 2019}

Citation: Khalid AA, Tuffour HO, Abubakariand A, Novor S. Conservation Tillage and Organic Matter management on Soil Structure. Madridge J Agric Environ Sci. 2019; 1(1): 14-18.

doi: 10.18689/mjaes-1000103

Copyright: (c) 2019 The Author(s). This work is licensed under a Creative Commons Attribution 4.0 International License, which permits unrestricted use, distribution, and reproduction in any medium, provided the original work is properly cited.

Published by Madridge Publishers

\begin{abstract}
Organic materials are important resources for the improvement of soil physical and chemical properties. This study was carried out to examine the impact of tillage and organic matter on some soil structural indices. The study was designed in a split-plot Randomized Complete Block with four replications. Hoe tillage and no-tillage were assigned to the main plot, whilst the subplot comprised cowpea residue, cattle manure, maize residues, elephant grass and control (no organic residue applied). The soil physical parameters measured were bulk density, total porosity, volumetric water content and aggregate stability. Bulk density was lower in the 2013 minor season than in the 2014 major season for all the treatments $\left(1.34 \mathrm{Mg} \mathrm{m}^{-3}-1.51 \mathrm{Mg} \mathrm{m}^{-3}\right)$. Porosity ranged from $42.98-49.28 \%$ in the second season (2013 minor season). The cattle manure treated plots produced the highest volumetric water content of $20.25 \%$ and the control gave the lowest value of $16.20 \%$ at the end of the last growing season (2014 major season). The highest aggregate stability $(74.91 \%)$ was recorded on cattle manure plots whilst the control gave the lowest value (71.11\%). Crop residues were identified to be good source of organic material for the improvement of soil physical properties.
\end{abstract}

Keywords: Aggregate stability; Bulk density; Organic matter; Porosity; Soil structure.

\section{Introduction}

The main purposes of tillage practice in agricultural fields are to provide better conditions for seed germination and emergence, control weeds, manage crop residues and manure to improve soil health, improve infiltration, which enhances soil moisture storage, and reduces runoff and erosion [1,2]. Crop residues can either be incorporated into the soil (tillage) or left on the soil surface as a mulch (no-tillage). According to Holland [3], soil structure and its stability can be improved by reduced tillage and notillage, which tend to increase soil moisture and organic matter content. This could be the result from the reduced or no use of heavy machinery which enhances aggregate formation and improves porosity and infiltration.

Zero tillage, mulching and cover cropping have also been recommended for sustainable soil health [4]. Conventional tillage is known to cause the breakdown and/or exposure of protected soil organic matter which accelerates its decomposition [5]. The breakdown of soil organic matter may increase soil compaction [6], slaking of aggregates, and surface sealing/ crusting, which reduces water infiltration, soil water holding capacity, and increases surface ponding, run off and erosion [7]. In view of this, tillage methods should be developed to provide a better soil-water-plant relationship for sustainable crop production. The objective of the study, therefore, was to evaluate the contribution of conservation tillage, and crop residue and manure application on the improvement of soil physical properties. 


\section{Materials and Methods}

\section{Description of study area}

The field experiment was carried out on the research fields of CSIR-Crops Research Institute at Fumesua $\left(01^{\circ} 36 \mathrm{~W}\right.$; $06^{\circ} 43 \mathrm{~N}$ ) in the moist semi-deciduous forest zone of Ghana with an elevation of $186 \mathrm{~m}$ above sea level. The area has a bimodal rainfall pattern with average annual rainfall of 1727.2 $\mathrm{mm}$ with mean minimum and maximum temperatures of $21^{\circ} \mathrm{C}$ and $31^{\circ} \mathrm{C}$, respectively. The mean annual relative humidity is $61 \%$ at noon and $95 \%$ in the morning. The soil at the experimental site is classified as Ferric Acrisol [8]. It has a thick surface layer and a slope of 1-5\%. It is a sandy loam with the top soil being dark brown in colour with a granular structure.

\section{Study design}

The study was conducted on plots that had previously been cultivated with cowpea. The study was laid out in a splitplot arranged in Randomized Complete Block Design (RCBD) with four replications. There were 8 main plots and 40 subplots which covered a total land area of $1456 \mathrm{~m}^{2}$. Hoe till (incorporation of organic materials with hoe) and no-tillage (application of organic material on the soil surface) were assigned to the main-plots while the sub-plots comprised cowpea residue (CR), maize straw (MSR), elephant grass (EGR), cattle manure (CM) and control (C) (absence of organic material). The experiment was carried out in 2013 and 2014 major seasons and 2013 minor season. The crop residues were dried and cut into pieces. They were applied two weeks before planting at a rate of 10 tons/ha. Cattle manure was also applied at a rate of 4 tons/ha the same day the crop residues were applied.

\section{Sample collection and analyses}

Moist soil samples collected with a core sampler from a depth of 0-15 cm after three days of heavy rainfall, when the soil was assumed to be at field capacity. Volumetric moisture content, bulk density and total porosity were determined from these samples as described by Klute [9]. Aggregate stability was determined using modified wet sieving method [10]. The data collected on various parameters was subjected to analysis of variance using Genstat software programme (2010). The means were separated using Least Significant Difference at $5 \%$ probability.

\section{Results and Discussion}

\section{Bulk density and total porosity}

Bulk density was measured after harvesting in each cropping season. The tillage treatments did not show significant $(P>0.05)$ effect on bulk density in all the three seasons as presented in table 1. Moreover, the organic material treatments and the control did not significantly $(P>0.05)$ affect bulk density in the major seasons of both years. In the minor season however, the residue treatments and cattle manure produced significantly lower $(P<0.05)$ values than the control. Specifically, in the minor season, bulk density decreased in the order: $\mathrm{C}>\mathrm{MSR}>\mathrm{EGR}=\mathrm{CM}>\mathrm{CR}$. Interactions between the tillage and organic material treatments did not show significant $(P>0.05)$ differences in all the three seasons. Bulk density values recorded showed somewhat seasonal variations. Values recorded in 2013 minor season declined slightly over values observed in the major season of the same year (i.e., 2013). Conversely, values recorded in 2014 major season showed marginal increments over those recorded in the 2013 minor season.

Table 1. Effects of tillage and organic materials management on bulk density.

\begin{tabular}{|l|c|c|c|}
\hline \multirow{2}{*}{ Treatment } & \multicolumn{3}{|c|}{ Bulk density (Mgm $\left.{ }^{-3}\right)$} \\
\cline { 2 - 4 } & 2013 Major season & 2013 Minor season & 2014 Major season \\
\hline Tillage & $1.48^{\mathrm{a}}$ & $1.46^{\mathrm{a}}$ & $1.53^{\mathrm{a}}$ \\
\hline No-tillage & $1.43^{\mathrm{a}}$ & $1.38^{\mathrm{a}}$ & $1.55^{\mathrm{a}}$ \\
\hline Hoe tillage & $1.50^{\mathrm{a}}$ & $1.51^{\mathrm{a}}$ & $1.52^{\mathrm{a}}$ \\
\hline Amendment \\
\hline Control & $1.45^{\mathrm{a}}$ & $1.37^{\mathrm{b}}$ & $1.55^{\mathrm{a}}$ \\
\hline Cattle manure & $1.42^{\mathrm{a}}$ & $1.34^{\mathrm{b}}$ & $1.49^{\mathrm{a}}$ \\
\hline Cowpea & $1.46^{\mathrm{a}}$ & $1.37^{\mathrm{b}}$ & $1.51^{\mathrm{a}}$ \\
\hline Elephant grass & $1.43^{\mathrm{a}}$ & $1.38^{\mathrm{b}}$ & $1.51^{\mathrm{a}}$ \\
\hline Maize & $\mathrm{NS}$ & $\mathrm{NS}$ & $\mathrm{NS}$ \\
\hline Lsd (0.05) & $\mathrm{NS}$ & 0.10 & $\mathrm{NS}$ \\
\hline Tillage & 2.50 & 2.50 & 0.90 \\
\hline Amendment & 4.30 & 3.30 & 1.30 \\
\hline CV (\%) & \multicolumn{4}{|l|}{} \\
\hline Tillage & Amendment &
\end{tabular}

NS means not significant at 5\%; ${ }^{a, b}$ Means with the same alphabet within a column are not statistically different.

The tillage treatments did not have any significant $(P>0.05)$ impact on total porosity in all the three seasons (Table 2). There were no significant differences $(P>0.05)$ among organic material treatments in 2013 and 2014 major seasons. However, in 2013 minor season, plots treated with organic materials produced significantly $(P<0.05)$ higher porosity values than the control, specifically in the increasing order of $\mathrm{C}<\mathrm{MSR}<\mathrm{EGR}<\mathrm{CM}<\mathrm{CR}$. However, the interactions between tillage and organic materials did not significantly $(P$ $>0.05$ ) affect porosity in all the three seasons.

Table 2. Effects of tillage and organic matter on total porosity.

\begin{tabular}{|c|c|c|c|}
\hline \multirow{2}{*}{ Treatments } & \multicolumn{3}{|c|}{ Total porosity (\%) } \\
\hline & 2013 Major season & 2013 Minor season & 2014 Major season \\
\hline \multicolumn{4}{|l|}{ Tillage } \\
\hline No-tillage & $44.29^{a}$ & $46.52^{\mathrm{a}}$ & $41.96^{a}$ \\
\hline Hoe tillage & $46.07^{a}$ & $48.01^{\mathrm{a}}$ & $41.51^{a}$ \\
\hline \multicolumn{4}{|l|}{ Amendment } \\
\hline Control & $43.42^{\mathrm{a}}$ & $42.98^{b}$ & $42.38^{a}$ \\
\hline Cattle manure & $45.20^{\mathrm{a}}$ & $48.15^{a}$ & $41.51^{a}$ \\
\hline Cowpea & $46.45^{a}$ & $49.28^{a}$ & $43.77^{a}$ \\
\hline Elephant grass & $44.81^{a}$ & $47.99^{a}$ & $42.89^{a}$ \\
\hline Maize & $46.04^{a}$ & $47.95^{\mathrm{a}}$ & $42.90^{\mathrm{a}}$ \\
\hline \multicolumn{4}{|l|}{ Lsd (0.05) } \\
\hline Tillage & NS & NS & NS \\
\hline Amendment & NS & 3.65 & NS \\
\hline \multicolumn{4}{|l|}{ CV (\%) } \\
\hline Tillage & 2.8 & 2.6 & 3.0 \\
\hline Amendment & 5.0 & 3.7 & 1.8 \\
\hline
\end{tabular}

NS means not significant at 5\%; ${ }^{a, b}$ Means with the same alphabet within a column are not statistically different 
Bulk density influences other physical properties as well as chemical and biological properties of the soil. The bulk density decreased marginally in the second season and increased in the last season (Table 1), confirming the fact that it is a dynamic property. Tillage operations (conventional) are known to initially decrease bulk density which tends to increase with time due to the settling of the soil particles under the impact of rain drop [11-13]. It is evident from table 1 that bulk density from the hoe tillage and no-tillage plots in the study was not significantly different. This could have resulted from the fact that the hoe tillage employed in this study did not cause much soil compaction as may be observed in conventional tillage, wherein wheel traffic could result in severe soil compaction. Rashidi and Keshavarzpour [14] found that soil bulk density was higher in no-tillage when compared to conventional tillage.

The organic materials had significant impact on bulk density only in the 2013 minor season. Cowpea residue generally had the lowest bulk density in the study indicating that crop residues could improve bulk density with positive impact on other soil properties. This might have been due to its lowest $\mathrm{C}: \mathrm{N}$ ratio, which possibly enhanced its decomposition with a loosening effect on the soil leading to the reduction in the soil bulk density. This may have a concomitant impact on infiltration rates. Soil porosity is an important factor in soil hydrology because it influences the movement of water in the soil [15]. In this study, tillage treatments did not differ significantly from each other in porosity in all the three seasons (Table 2). Apart from the short-term nature of the study, this may also be due to the fact that the two tillage systems used did not cause much soil compaction. The organic material treatments in the study generally improved total porosity probably due to their positive impact on soil structure and activities of soil organisms. Tangyuan et al. [16] reported that soil total porosity in the 0 to $10 \mathrm{~cm}$ soil layer increased under conventional tillage and residue retention. Proper management of crop residues is therefore an essential means of enhancing soil porosity.

\section{Volumetric water content}

The volumetric water content was measured eight weeks after planting. There were no significant $(P>0.05)$ differences between no-tillage and hoe tillage treatments in both 2013 major and minor seasons (Table 3). However, in the 2014 major season, no-tillage resulted in significantly $(P<0.05)$ higher moisture content than the hoe tillage treatment. The organic materials also did not show significant differences in 2013 major and minor seasons with respect to volumetric water content. In 2014 major season, significant differences $(P<0.05)$ were observed between volumetric water content under the organic material treatments and the control plots. Cattle manure, cowpea and elephant grass residues treated plots stored more water than the control. Maize residue plots did not differ significantly $(P>0.05)$ from the other treatments. Cattle manure had the highest value of $20.25 \%$ whilst the control had the lowest value of $16.30 \%$. The tillage and organic materials interactions did not significantly affect soil moisture content in all the three seasons. In the last season, volumetric water content increased in the order: $\mathrm{C}<\mathrm{MSR}<\mathrm{EGR}<\mathrm{CR}<\mathrm{CM}$.

Table 3. Effects of tillage and organic materials management on volumetric water content.

\begin{tabular}{|l|c|c|c|}
\hline \multirow{2}{*}{ Treatments } & \multicolumn{3}{|c|}{ Volumetric water content (\%) } \\
\cline { 2 - 4 } & 2013 Major season & 2013 Minor season & 2014 Major season \\
\hline Tillage & $13.75^{\mathrm{a}}$ & $16.2^{\mathrm{a}}$ & $19.61^{\mathrm{a}}$ \\
\hline No-tillage & $14.09^{\mathrm{a}}$ & $17.09^{\mathrm{a}}$ & $17.73^{\mathrm{b}}$ \\
\hline Hoe tillage & $13.51^{\mathrm{a}}$ & $15.80^{\mathrm{a}}$ & $16.30^{\mathrm{b}}$ \\
\hline Amendment \\
\hline Control & $13.96^{\mathrm{a}}$ & $17.03^{\mathrm{a}}$ & $20.25^{\mathrm{a}}$ \\
\hline Cattle manure & $15.06^{\mathrm{a}}$ & $18.52^{\mathrm{a}}$ & $19.71^{\mathrm{a}}$ \\
\hline Cowpea & $13.50^{\mathrm{a}}$ & $16.55^{\mathrm{a}}$ & $19.40^{\mathrm{a}}$ \\
\hline Elephant grass & $13.56^{\mathrm{a}}$ & $16.63^{\mathrm{a}}$ & $17.68^{\mathrm{a}}$ \\
\hline Maize & $\mathrm{NS}$ & 1.73 \\
\hline Lsd (0.05) & $\mathrm{NS}$ & $\mathrm{NS}$ & 2.71 \\
\hline Tillage & $\mathrm{NS}$ & 7.50 & 6.00 \\
\hline Amendment & 7.60 & 7.90 & 4.10 \\
\hline CV (\%) & 9.80 & \multicolumn{3}{|l|}{} \\
\hline Tillage & Amendment &
\end{tabular}

NS means not significant at $5 \%$; ${ }^{a, b}$ Means with the same alphabet within a column are not statistically different

The volumetric water content was determined as an indicator of the amount of water that was retained in the soil at field capacity. The results showed that tillage and no tillage did not have any significant impact in the first two seasons (Table 3). In the last season, however, the volumetric water content was higher in no-tillage than tillage plots, possibly due to their cumulative effects over time. Differences in soil properties under tillage practices are noticeable with time [17]. Similarly, Sharma et al. [18] reported that the highest amount of soil moisture was retained in no-tillage when compared with minimum and conventional tillage systems. Assuming a constant rate of temperature and possibly insignificant water in deep percolation, soil moisture depletion would be mainly through evaporative loss [19]. In this context no-tillage was a better practice in soil moisture conservation (as observed in the third season) due to the mulch residues on the soil surface.

The trend observed for the organic material applications showed that their effects on the soil physical properties can only be noticed with time. Moisture content was found to be higher in the organic materials treated plots than the control plots but the differences were not significant in the first two seasons (Table 3). However, significant improvement was observed in the last season. This could have resulted from improvements in the soil structure owing to the decomposition of the organic materials applied in the previous two seasons. The mulch on the no-till plots possibly reduced runoff and increased infiltration. The surface mulch also might have reduced the rate of evaporation by mitigating turbulent air movement over the soil surface as compared to the bare soil surface. In addition, the grass mulch reduced the latent heat flux in the soil and decrease the rate of evaporation, which increased the accumulation of soil water [20]. Surface mulch is also known to serve as a barrier to restrict water movement over the soil surface this enhancing water infiltration and 
storage. Higher water content as a result of surface cover under no-tillage has also been linked with lower soil temperature [21]. Tilling of plots usually expose surface soil to water loss through evaporation. This implies that proper management of crop residues can enhance soil moisture conditions.

\section{Aggregate stability}

The aggregate stability was measured at the end of the last cropping season. Hoe tillage and no-tillage did differ significantly $(P<0.05)$ with respect to aggregate stability (Table 4). The organic materials produced significantly more stable aggregates than the control. However, there were no significant differences between crop residues and cattle manure plots. The effect of the organic materials on aggregate stability was in the order: $\mathrm{CM}>\mathrm{CR}>\mathrm{MSR}>\mathrm{EGR}>\mathrm{C}$. Tillage and organic materials interacted significantly $(p<0.05)$ to affect aggregate stability. Hoe tillage with organic materials generally produced significantly higher values than no-tillage with organic materials. Hoe tillage interacted with cattle manure to produce the highest aggregate stability of $76.88 \%$ whilst the no-tillage interacted with the control to produce the lowest aggregate stability of $70.27 \%$.

Table 4. Effects of tillage and organic materials management on aggregate stability

\begin{tabular}{|l|c|}
\hline Treatments & Aggregate stability (\%) \\
\hline Tillage & $73.06^{\mathrm{a}}$ \\
\hline No-tillage & $74.34^{\mathrm{a}}$ \\
\hline Hoe tillage & $71.11^{\mathrm{b}}$ \\
\hline Amendment & $74.91^{\mathrm{a}}$ \\
\hline Control & $74.66^{\mathrm{a}}$ \\
\hline Cattle manure & $73.61^{\mathrm{a}}$ \\
\hline Cowpea & $74.20^{\mathrm{a}}$ \\
\hline Elephant grass & \\
\hline Maize & $\mathrm{NS}$ \\
\hline Lsd (0.05) & 1.68 \\
\hline Tillage & 2.21 \\
\hline Amendment & \\
\hline Interaction & 2.00 \\
\hline CV (\%) & 0.50 \\
\hline Tillage & 1.17 \\
\hline Amendment & \\
\hline Interaction & \\
\hline
\end{tabular}

NS means not significant; ${ }^{a, b}$ means with the same alphabet are not statistically different

Aggregate stability is an important soil property which affects immensely soil sustainability and crop production. It is an indicator of organic matter content, biological activity, and nutrient cycling and therefore soil quality. The aggregate stability did not differ between hoe till plots and no-till plots possibly due to the short time nature of the study. The organic material treatment plots produced higher aggregate stability than the control plots due to the lower soil organic carbon content of the control plots. Haynes and Swift [22] stated that lower soil organic carbon can decrease aggregate stability. This is because soil organic matter is an essential factor for soil structure development and aggregate stability [23]. This implies that organic materials have great propensity to prevent rapid deterioration of soil structure (through destabilization of aggregates) in cultivated soils.

\section{Conclusion}

The current study suggests that different tillage treatments and application of organic materials affected the soil physical properties. Specifically, the no tillage treatment and application of organic materials effectively improved the soil structure, soil water holding capacity as evidenced by the soil moisture contents, and strengthened the stability of water-stable soil aggregates. Therefore, conservation tillage in combination with proper management of residue mulching or organic matter application is a better option for sustainable soil and environmental management for farmers, especially those with low economic status.

\section{Acknowledgement}

The authors wish to express their profound gratitude to the Alliance for a Green Revolution in Africa (AGRA) for the financial support received for the research.

\section{Authors Competing Interest}

The authors declare that they have no competing interests.

\section{References}

1. Steiner K. Conservation Tillage - Gateway to Food Security and Sustainable Rural Development. Impact of Conservation Tillage on Soil Quality. African Conservation Tillage Network. Information Series No. 4; 2002.

2. Koller I. Techniques of soil tillage. In: Adel El Titi (Ed). Soil tillage in agroecosystems. CRC Press, Boca Raton, FL USA. 2003: 1-25.

3. Holland JM. The environmental consequences of adopting conservation tillage in Europe: reviewing the evidence. Agric Ecosys Environ. 2004; 103(1): $1-25$

4. Saha R, Chaudhary RS, Somasundaram J. Soil Health Management under Hill Agroecosystem of North East India. App Environ Soil Sci. 2012; 2012: 1-9.

5. Nicolardot B, Recous S, Shili I, Gréhan E, Thiérbeau P, Laurent F. Shortterm effect of converting soil tillage on soil $\mathrm{C}$ and $\mathrm{N}$ fluxes. In: Proceedings of 15th nitrogen workshop: towards a better efficiency in nitrogen use. Spain Fundacio Universitat de lleida; 2007.

6. Raper RL. Agricultural traffic impacts on soil. J Terra Mech. 2005; 42(3-4): 259-280.

7. Tuffour HO, Bonsu M, Quansah C, Abubakari A. A physically-based model for estimation of surface seal thickness. Int J Ext Res. 2015; 4: 60-64.

8. The state of food and agriculture, 1990 - FAO.

9. Klute A. Methods of Soil Analysis. 1987.

10. Kemper WD, Rosenau RC. Aggregate stability and size distribution. In: Klute A (Ed). Methods of soil analysis. Part 1. Agronomy Monograph 9. 2nd edition, Madison, Wisconsin, 1986: 425-442.

11. Le Bissonais $Y$, Renaux $B$, Delouche $H$. Interactions between soil properties and moisture content in crust formation, runoff and interrill erosion from till loess soil. Catena. 1995; 25(1-4): 33-46.

12. Le Bissonais $Y$, Benkhadra $H$, Chaplot $V$, Fox D, King D, Daroussin J. Crusting, runoff and sheet erosion on silty loamy soils at various scales and upscaling from M2 to small catchments. Soil Till Res. 1998; 46(1-2): 69-80.

13. Amegashie KB. Simulating the response of maize grain yield to tillage and different soil fertility measures in the semi-deciduous forest zone of Ghana. Ph.D. Thesis, Faculty of Agriculture, Kwame Nkrumah University of Science and Technology, Kumasi, Ghana; 2014.

14. Rashidi M, Keshavarzpour F. Effect of different tillage methods on soil physical properties and crop yield of Melon (Cucumis melo). ARPN J Agric Biol Sci 2008; 3(1): 43-48. 
15. Aikins SHM, Afuakwa JJ. Effect of four different tillage practices on soil physical properties under cowpea. Agric Bi J North Am. 2012; 2151-7517.

16. Tangyuan N, Bin $H$, Nianyuan J, Shenzhong T, Zengjia L. Effects of conservation tillage on soil porosity in maize-wheat cropping system. Plant Soil Environ. 2009; 55(8): 327-333.

17. Murdock LM, Call D, James J. Compaction, tillage method and sub soiling effect on crop production. UK Cooperative Extension Service Article AGR197, College of Agriculture, University of Kentucky. 2008.

18. Sharma P, Abrol V, Sharma RK. Impact of tillage and mulch management on economics, energy requirement and crop performance in maizewheat rotation in rain fed sub humid inceptisols. India. Eur J Agron. 2011; 34(1): 46-51.
19. Serme I. Growth and yield of sorghum under different conservation tillage and water and nutrient management practices in the South Sudan zone of Burkina Faso. Ph.D. Dissertation, Kwame Nkrumah University of Science and Technology, Kumasi, Ghana; 2014.

20. Bonfil D, Mufradi I, Klitman S, Asido $S$. Wheat grain yield and soil profile water distribution in a no-till arid environment. Agron J. 1999; 91(3): 368-373.

21. Rasmissen KJ. Impact of ploughless soil tillage on yield and soil quality. A Scandinavian review. Soil Till Res. 1999; 53(1): 3-4.

22. Haynes RJ, Swift RS. Stability of soil aggregates in relation to organic constituents and soil water content. Eur J Soil Sci 1990; 41(1): 73-83.

23. Shepherd MA, Harrison R, Webb J. Managing soil organic matterimplications for soil structure on organic farms. Soil Use and Management. 2002; 18(1): 284-292. 